\title{
Iodine concentration and prevalence of thyroid disease in older people after salt iodization in Turkey
}

Volkan Atmis, ${ }^{1}$ Buket Bülbül, ${ }^{2}$ Remzi Bahşi, ${ }^{1}$ Mesut Gümüşsoy, ${ }^{3}$ Ahmet Yalçin, ${ }^{1}$ Zeynal Doğan, ${ }^{4}$ Özgür Demir, ${ }^{5}$ Murat Erdoğan ${ }^{5}$ and Teslime Atli ${ }^{6}$

${ }^{1}$ Department of Geriatrics, Ankara University, Ankara, Turkey. ${ }^{2}$ Department of Endocrinology and Metabolism, Batman State Hospital, Batman, Turkey. ${ }^{3}$ Department of Gastroenterology, Ankara University, Ankara, Turkey. ${ }^{4}$ Department of Gastroenterology, Elazığ Medical Park Hospital, Elazığ, Turkey. ${ }^{5}$ Department of Endocrinology and Metabolism, Ankara University, Ankara, Turkey. ${ }^{6}$ Department of Geriatrics, Near East University, Lefkoşa, Cyprus. (Correspondence to: Volkan Atmiş: volkanatmis@hotmail.com).

\begin{abstract}
Background: Iodine uptake is a main factor affecting thyroid disease. In Turkey, mandatory salt iodization began in 1999-2000.

Aims: This study in 2009 determined the prevalence of thyroid diseases in older people in Mamak district, Ankara after iodization to ascertain if salt iodization alone is sufficient to reach adequate iodine levels in the older population.

Methods: All Mamak residents $\geq 65$ years were eligible for inclusion in the study. Demographic data and medical history were recorded. All participants had a thyroid ultrasound. Blood samples were taken to assess thyroid function and autoantibodies, and urine samples to assess iodine concentration. Participants with low levels of thyroid stimulating hormone underwent scintigraphy to assess thyroid uptake. Fine-needle aspiration biopsy was done of nodules $\geq 1.5 \mathrm{~cm}$ where thyroid stimulating hormone was not suppressed.
\end{abstract}

Results: Of 1200 eligible residents, 979 were included. Their mean age was 70.9 (standard deviation (SD) 5.7) years; 49.7\% were women. Mean urinary iodine concentration was 98 (SD 81.29) $\mu \mathrm{g} / \mathrm{L}$. Goitre was found in 18.2\% (89/487) of women and $6.7 \%(33 / 492)$ of men $(P<0.001)$ and $43.8 \%(428 / 979)$ had nodules. Subclinical hypothyroidism was found in $5.8 \%$ (57/979) of the participants, overt hyperthyroidism in $0.8 \%$ (8/979), subclinical hyperthyroidism in $2.2 \%(22 / 979)$ and T3 thyrotoxicosis in $0.3 \%$ (3/979). Toxic multinodular goitre and toxic adenoma caused $80 \%$ of hyperthyroidism cases. Biopsy detected no malignant pathology.

Conclusion: After salt iodization, iodine levels have not yet reached favourable levels in older people. Iodization of salt seems insufficient to achieve these levels in older people; alternative iodine supplementation should be considered.

Keywords: goitre, hyperthyroidism, hypothyroidism, iodized salt, elderly people, Turkey

Citation: Atmiş A; Bülbül B; Bahşi R; Gümüşsoy M; Yalçin A; Doğan Z; el al. Iodine concentration and prevalence of thyroid disease in older people after salt iodization in Turkey. East Mediterr Health J. 2021;27(2):151-158. https://doi.org/10.26719/2021.27.2.151

Received: 21/08/19; accepted: 22/01/20

Copyright (c) World Health Organization (WHO) 2021. Open Access. Some rights reserved. This work is available under the CC BY-NC-SA 3.0 IGO

license (https://creativecommons.org/licenses/by-nc-sa/3.o/igo)

\section{Introduction}

The thyroid gland affects metabolism and development of all tissues by secreting triiodothyronine $\left(\mathrm{T}_{3}\right)$ and tetraiodothyronine (T4) hormones. The main component of $\mathrm{T} 3$ and $\mathrm{T} 4$ hormones is iodine (1). All of the iodine in our body is taken orally, absorbed from the small intestine and concentrated in the thyroid gland. Iodine acts directly on almost all enzymatic steps in the thyroid gland (synthesis and destruction) and is continually reused, while excess unused iodine is excreted through the renal tract (2). Therefore, urinary iodine concentration reflects the amount of iodine that a person has received, especially in the past 24 hours (3). According to the World Health Organization (WHO), International Council for Control of Iodine Deficiency Disorders, the daily iodine intake should be $150-200 \mu \mathrm{g}$ for adults with a median iodine excretion of $<100 \mu \mathrm{g} /$ day (4). While thyroid volume and nodularity are high in iodine-deficient regions, autoimmune thyroid diseases and follicular thyroid carcinomas are more common in regions with excessive iodine intake (5).
The frequency of thyroid diseases increases with age. This increase seems to be due to the increase in subclinical hypo- and hyperthyroidism rather than overt hypo- and hyperthyroidism (6). Levels of thyroid stimulating hormone (TSH) increase with age and $\mathrm{T}_{4}$ metabolism changes, but the effects of these changes on physiology are still unclear and published research reports contradictory findings (7). Evidence also shows that thyroid nodules and carcinoma prevalence increase with age (8).

In 1994, the Ministry of Health in Turkey started the Iodine Deficiency Disorders Control and Salt Iodization Programme and iodization of table salt was obligatory by 1999 (9). The aim of salt iodization was to eliminate iodine deficiency from the country by the end of 2005 . The use of iodized salt in Turkey was 18\% in 1995, which rose to $73.5 \%$ by the end of 2007 (9,10). A study on schoolaged children in Ankara, reported that the prevalence of goitre decreased from $25.0 \%$ in 1997 to $1.3 \%$ in 2007 after iodization which indicated adequate iodine prophylaxis $($ median urinary iodine concentration $=117 \mu \mathrm{g} / \mathrm{L})(11)$. 
No studies have been done to evaluate the effectiveness of salt iodization in Turkey and the prevalence of thyroid diseases in older people after salt iodization. In this study, we aimed to measure urinary iodine concentrations in a large sample of community-dwelling people aged more than 65 years to determine: (i) whether effective iodization has been reached since iodization of table salt, and (ii) the current prevalence of thyroid disease.

\section{Methods}

\section{Study design and sample}

This cross-sectional study was part of a 2009 health project entitled: Health Screening in Older People in the Mamak district of Ankara. The project was planned by the Department of Geriatrics and Department of Endocrinology and Metabolism at Ankara University. The aims of the screening were to obtain demographic and health data, perform primary health screening and evaluate geriatric syndromes. All residents aged 65 years and older in the Mamak district of Ankara in April-July 2009 were invited to the health screening study by the municipalities through telephone calls and written (delivered through post boxes) and verbal announcements (e.g. television announcement and announcements at mosques) once screening had started. We included all elderly people who were willing to participate. Exclusion criteria were: advanced stage organ failure, inability to communicate, mobility disorders and/or being bedbound as data were collected at mosques or municipalities, not at home.

\section{Data collection}

We interviewed the participants and recorded demographic data, history of thyroid disease, use of thyroid hormone and/or anti-thyroid medication, history of thyroid operation and history of radioactive iodine treatment. All participants underwent thyroid ultrasonography. Urine samples were collected for urinary iodine and blood samples for thyroid hormones (free $\mathrm{T}_{3}$, free $\mathrm{T} 4$ and TSH) and autoantibodies (antithyroid peroxidase and antithyroglobulin). One laboratory of the Ankara University Faculty of Medicine performed all the laboratory tests. This laboratory was certified for quality by the Ministry of Health. We used an electrochemiluminescence immunometric assay method for the thyroid function tests (Roche Modular Analytics E70 device).

The same physician (an experienced endocrinologist who has worked on thyroid diseases, specifically endemic goitre, for over 20 years) performed the thyroid ultrasonography (General Electric Logic 200 ultrasonography device and $7.5 \mathrm{MHz}$ linear probe). The longitudinal, transverse and anteroposterior dimensions of each lobe were measured as well as any nodules detected. We calculated the thyroid gland and nodule volumes were using the ellipsoid body formula (12). We considered volumes of $18 \mathrm{~mL}$ and above for women and $25 \mathrm{~mL}$ for men as an indication of goitre $(12,13)$. We categorized the thyroid gland parenchyma (echogenicity) into four groups - homogeneous, slightly heterogeneous, moderately heterogeneous and severely heterogeneous - based on the ultrasonography images.

Participants' urine samples were taken in the morning after overnight fasting and stored in deiodized tubes at $4{ }^{\circ} \mathrm{C}$ until analysis. We used the colorimetric SandellKolthoff reaction to measure urinary iodine level (4).

Participants were diagnosed with thyroid conditions as follows: (i) low TSH and high free T4 was diagnosed as overt hyperthyroidism; (ii) low TSH and normal free T4 and free $\mathrm{T} 3$ was diagnosed as subclinical hyperthyroidism; (iii) low TSH, normal free $\mathrm{T}_{4}$ and high free $\mathrm{T} 3$ was diagnosed as T3 thyrotoxicosis; (iv) high TSH and low free T4 was diagnosed as overt hypothyroidism; and (v) high TSH and normal free T4 level was diagnosed as subclinical hypothyroidism. We considered participants with a median urinary iodine excretion of $<100 \mu \mathrm{g} /$ day were iodine deficient.

We further evaluated participants with hyperthyroidism with thyroid scintigraphy and thyroid I-131 uptake. The same physician who performed ultrasonography also performed thyroid fine-needle aspiration biopsy for participants who had nodules larger than $1.5 \mathrm{~cm}$ and without suppressed TSH levels. A cytologist at the Cytology Department of the Faculty of Medicine, Ankara University analysed the samples.

\section{Statistical analysis}

We analysed data using the SPSS, 22.0 program. We calculated results as mean and standard deviation (SD) and percentages. We used the chi-squared test to examine statistical associations between independent categorical variables. We analysed the correlation between categorical variables by determining the Spearman rank-order correlation coefficient $\left(r_{s}\right)$. We transformed continuous variables into categorical variables for the Spearman rank-order correlation test. $P<0.05$ was considered statistically significant.

\section{Ethical considerations}

The institutional review board of Ankara University approved the study. Informed consent was taken from all participants. Treatment and follow-up was offered to every participant found to have inadequate iodine and thyroid disease.

\section{Results}

Over a 3-month period (April-July 2009), 1200 participants aged 65 years and more in the Mamak region of Ankara expressed interest in participating in the study. Those excluded were: 76 with advanced stage organ failure, 49 who were unable to communicate, 37 with mobility disorders and/or were bedbound and 59 with incomplete laboratory tests $(n=59)$. Thus, 979 participants were included in the study, 492 (50.3\%) men and $487(49.7 \%)$ women. The mean age of the participants was 70.9 (SD 5.7) years: 70.5 (SD 6.08) years for women and 71.4 (SD 5.41) years for men. As regards residence, 42.7\% (418/979) of the participants had been born in Ankara, 
$76.1 \%$ (745/979) had spent more than 30 years of their life in Ankara and (89 8\%) (879/979) had been living in Ankara for the past 10 years.

When the histories of thyroid disease were evaluated for the period after iodization, $24(2.4 \%)$ participants reported having thyroid disease. Table 1 shows the thyroid diseases of the participants.

Mean TSH level of the participants was 2.38 (SD 5.41) mIU/L, free T4 level was 16.34 (SD 5.535) pmol/L and free $\mathrm{T} 3$ was 41.391 (SD 11.971) pmol/L. The mean and median urinary iodine concentrations of the participants were 773.03 (SD 640.57) nmol/L and $929.84 \mathrm{nmol} / \mathrm{L}$, respectively, with a range of 7.88 $3546 \mathrm{nmol} / \mathrm{L}$. Interquartile range of the urinary iodine concentration was $717.08 \mathrm{nmol} / \mathrm{L}:$ Q1 was $504.32 \mathrm{nmol} / \mathrm{L}$ and Q3 was $1213.52 \mathrm{nmol} / \mathrm{L}$.

Thyroid autoantibody was high in $13.3 \%$ (130/979) of our participants: $9.3 \%$ (91/979) had a high antithyroid peroxidase antibody levels (>35 IU/mL), 9.0\% (88/979) had a high anti-thyroglobulin antibody levels (>65 IU/ $\mathrm{mL}$ ) and 5.0\% (49/979) had high levels of both antibodies. Thyroid autoantibodies levels were high in $16.8 \%$ of women and in $9.7 \%$ of men, a statistically significant difference $(P<0.001)$.

The prevalence of newly diagnosed functional thyroid disorders and high thyroid autoantibodies are shown in Table 2. About $6 \%$ of the participants had subclinical hypothyroidism and $2 \%$ had subclinical hyperthyroidism, while $9 \%$ each had high antithyroid peroxidase and high antithyroglobulin.

Most participants (698 (71.3\%)) had homogeneous thyroid gland parenchyma, $184(18.8 \%)$ had mildly heterogeneous parenchyma, 71 (7.3\%) had moderately heterogeneous parenchyma and $26(2.7 \%)$ had severely heterogeneous parenchyma. We detected goitre in 122/979 (12.5\%) participants; 89/487 (18.3\%) women and $33 / 492(6.7 \%)$ men. The prevalence of goitre was significantly higher in women than men $(P<0.001)$. Of the 122 participants with goitre, $91(74.6 \%)$ had iodine deficiency. Ultrasonography detected nodules in 428/979 $(43.7 \%)$ of the participants, $241 / 487(49.5 \%)$ women and $187 / 492(38.0 \%)$ men $(P<0.001)$. Of all the participants, $243 / 979(24.8 \%)$ had single nodules and $185 / 979(18.9 \%)$ had multiple nodules. Of a total of 655 nodules, 140 (21.4 $\%)$ were $\leq 1 \mathrm{~cm}$ in diameter, $278(42.4 \%)$ were in between 1 and $2 \mathrm{~cm}$ and $237(36.2 \%)$ were $\geq 2 \mathrm{~cm}$. A significant

\begin{tabular}{lc}
\hline $\begin{array}{l}\text { Table } 1 \text { History of thyroid disease and thyroidectomy in older } \\
\text { people after nationwide salt iodization, Turkey }\end{array}$ \\
$\begin{array}{lc}\text { Disease } & \text { No) } \\
\text { (n = 979) }\end{array}$ \\
Goitre & $4(0.4)$ \\
Hypothyroidism & $7(0.7)$ \\
Hyperthyroidism & $8(0.8)$ \\
Thyroidectomy & $5(0.5)$ \\
Total & $24(2.4)$ \\
\hline
\end{tabular}

\begin{tabular}{|c|c|}
\hline Variable & $\begin{array}{c}\text { No. (\%) } \\
(n=979)\end{array}$ \\
\hline Overt hypothyroidism & $0(0.0)$ \\
\hline Subclinical hypothyroidism & $57(5.8)$ \\
\hline Overt hyperthyroidism & $8(0.8)$ \\
\hline Subclinical hyperthyroidism & $22(2.2)$ \\
\hline T3 thyrotoxicosis & $3(0.3)$ \\
\hline High antithyroid peroxidase & $91(9.3)$ \\
\hline High antithyroglobulin & $88(9.0)$ \\
\hline High anti-thyroid peroxidase and antithyroglobulin & $49(5.0)$ \\
\hline
\end{tabular}

positive correlation was found between parenchymal echogenicity and TSH $\left(r_{s}=0.76, P<0.001\right)$.

TSH was suppressed in 33/979 (3.4\%) participants, $0.8 \%$ (8/979) had overt hyperthyroidism, 2.2\% (22/979) had subclinical hyperthyroidism and 0.3\% (3/979) had T3 thyrotoxicosis. In $81.8 \%$ (27/33) of our participants with hyperthyroidism, toxic multinodular goitre and toxic adenoma were detected.

Thyroid scintigraphy and thyroid I-131 uptake were evaluated in 20 participants who were diagnosed with overt hyperthyroidism. Of these $20,11(55.0 \%)$ had toxic multinodular goitre, five $(25.0 \%)$ had toxic nodular goitre and three (15.0\%) had diffuse toxic goitre; one patient had hyperthyroidism secondary to thyroiditis. Fine-needle aspiration biopsy was recommended to 398 participants with nodule size $\geq 1.5 \mathrm{~cm}$ and without suppressed TSH. We found no malignant pathology in the cytology of 60 participants who agreed to allow thyroid fine-needle aspiration biopsy.

\section{Discussion}

In our study, the mean value of urinary iodine concentration of participants was $98 \mu \mathrm{g} / \mathrm{L}$. Although this is very close to the level accepted as normal iodine intake by WHO $(100 \mu \mathrm{g} / \mathrm{L})$, the urinary iodine concentration of our study group was in the upper limit of mild iodine deficiency 10 years after iodization of table salt. Some studies have shown that 12 years was not enough to reach the desired urinary iodine concentration after iodization. In a similar study on older people in Ankara in 1999 before iodization, the urinary iodine concentration was $59 \mu \mathrm{g} / \mathrm{L}$, which is consistent with mild-to-moderate iodine deficiency (14). We could not find any data after that time. In a study on schoolchildren in Ankara, urinary iodine concentration was $25.5 \mu \mathrm{g} / \mathrm{L} 1997$ before iodization, and in 2007, after iodization, urinary iodine concentration had increased to $135 \mu \mathrm{g} / \mathrm{L}$ (11). There may be several reasons why older age groups are not consuming sufficient amounts of iodine: (i) low consumption of salt and foods rich in iodine because of dietary limitations secondary to disease; (ii) economic limitations in accessing foods with 
high iodine content (for example, iodized salt is almost four times more expensive than the ordinary salt); and (iii) cultural differences in food preparation (e.g. using non-iodized salt for pickles, sausages and cooking, or needing to restrict salt intake because of hypertension which is common in older people), which are consumed nearly every day. Salt restriction to $2-6 \mathrm{~g} /$ day is frequent in older age groups, mainly because of chronic diseases (e.g. hypertension, congestive heart failure and chronic kidney disease). In Turkey, $50-70 \mathrm{mg} / \mathrm{kg}$ potassium io-

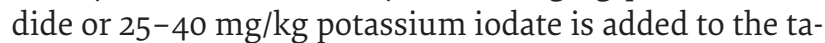
ble salt. Therefore, the elderly need to consume at least $4 \mathrm{~g}$ a day of salt to obtain the iodine requirement from salt.

We found goitre in $12.5 \%$ of the participants with significantly more women having the condition than men $(P<0.001)$. A study in Ankara before iodization reported a higher prevalence of goitre in older people ( $\geq 65$ years) $-28.2 \%$ (33.1\% in women and $18.0 \%$ in men) (14). This difference indicates a significant decrease in the prevalence of goitre after iodization in older people. Similarly, in a study conducted in school-aged children in Ankara, the prevalence of goitre decreased from $25.0 \%$ to $1.3 \%$ after iodization (7). A study in a region of the Islamic Republic of Iran with severe iodine deficiency showed that iodine deficiency persisted 12 years after iodization despite an increase in urinary iodine concentration and a significant decrease in goitre (15).

Iodine intake is the most important factor affecting the prevalence of goitre. In Denmark, in the iodinedeficient Jutland region (with a urinary iodine concentration of $38 \mu \mathrm{g} / \mathrm{L}$ ), goitre in older people was more common compared than in Iceland with iodine excess (urinary iodine concentration: $150 \mu \mathrm{g} / \mathrm{L}$ ) particularly in women: $12.2 \%$ in women in Jutland compared with $1.9 \%$ in Iceland (16). In a study in England, the prevalence of goitre in an area with sufficient iodine intake was 15.5\% (17). In our study, the prevalence of goitre was similar to the prevalence in Isfahan, Islamic Republic of Iran, which reported that 15 years after iodization, goitre was still endemic with a prevalence of $19 \%$ and urine iodine concentration was low (18).

In our study, thyroid nodule/nodules were detected in ultrasonography in $43.8 \%$ of our participants. In the Ankara study before iodization, the prevalence of nodules was $37.4 \%$ (14). A slight increase in nodule frequency after iodization may be due to differences in the ultrasonography device used and the people performing the procedure. In studies in areas with sufficient iodine intake, the incidence of nodules was reported to be 20.2$29.6 \%$ and this rate was $34.1 \%$ in regions with excess iodine intake $(19,20)$. These studies had a younger median age group compared with our participants, so our findings may represent the increase in nodules because of ageing.

We found no malignant pathology in the 60 biopsies of participants with thyroid nodules of $\geq 1.5 \mathrm{~cm}$ in diameter. Malignant pathology was also not found in the older people in the study conducted in Ankara before iodization (14). These results indicate that despite the increase in the prevalence of nodules with age, nodules are usually present with thyrotoxicosis, and therefore TSH should be evaluated first in older people. In addition, biopsy needs to be performed only in cases thought to be at high risk of malignancy in older people with thyroid nodules.

In our study, $5.8 \%$ of the participants had subclinical hypothyroidism, while none had overt hypothyroidism. The prevalence of subclinical hypothyroidism was $4.2 \%$ in elderly people living in Ankara before iodization even though the participants in the Ankara study before iodization were older than the participants in our study and the ratio of women was higher (14). In Denmark, the prevalence of hypothyroidism was $12.9 \%$ in older people in the Skagen region where iodine intake was sufficient (urinary iodine concentration $=177 \mu \mathrm{g} / \mathrm{L}$ ) and only two $(1.0 \%)$ cases of overt hypothyroidism were reported (21). The prevalence of hypothyroidism in the Danish study is much higher than in our study. Differences in the demographics of the participants and study regions may have contributed to the difference in hypothyroidism rates: $61 \%$ of the participants in the Danish study were women, the mean age was higher and the iodine levels were higher. In a study which included elderly people in Slovakia, who had been receiving iodine prophylaxis for about 50 years, the prevalence of overt and subclinical hypothyroidism was $1.5 \%$ and $10.4 \%$, respectively (23). The higher rates in Slovakia may be because of the longer duration of iodine prophylaxis. Many studies have shown that the prevalence of overt and subclinical hypothyroidism increases with iodization of, for example, water or salt $(17,21-27)$. Similar to the literature, the prevalence of subclinical hypothyroidism before iodization was $2.6 \%$ (14) and it was 5.8\% in our study after iodization. The increase in prevalence of hypothyroidism after iodization may be linked to the inhibition of thyroid hormone synthesis as a result of the intake of iodine $(28,29)$. Another reason may be lymphocyte infiltration and increased autoimmune thyroid diseases of the thyroid gland as a result of ageing in animal and humans $(20,30,31)$. Lastly, although in vitro studies show that excess iodine intake increases apoptosis in thyroid follicular cells, no epidemiological study has clearly shown the relation between iodine intake and thyroid autoimmunity (32).

In our study, TSH was suppressed in 33 (3.4\%) participants, $0.8 \%$ had overt hyperthyroidism, $2.2 \%$ had subclinical hyperthyroidism and $0.3 \%$ had $\mathrm{T}_{3}$ thyrotoxicosis. In $80 \%$ of our participants with hyperthyroidism, toxic multinodular goitre and toxic adenoma were detected. The Ankara study reported a prevalence of $3.8 \%$ for overt hyperthyroidism, $0.8 \%$ for T3 thyrotoxicosis, $6.2 \%$ for subclinical hyperthyroidism, and $73.3 \%$ for toxic multinodular goitre and toxic adenoma in elderly people before iodization (14). Hyperthyroidism frequency is reported to decrease in older people because of iodization but the etiology of hyperthyroidism is similar. We found a decreased frequency of hyperthyroidism. Some studies support and 
others contradict our findings, and we do not know what the reason(s) are for the differences. For example, in a study of elderly people in eastern Europe, the prevalence of hyperthyroidism was similar in participants with and without iodine deficiency ( $2.3 \%$ and $3.0 \%$, respectively) (22). In another study of elderly people, the prevalence of hyperthyroidism was $9.7 \%$ in a region of intermediate iodine deficiency and $1.0 \%$ in a region with iodine excess (16). Another study in Denmark found the prevalence of hyperthyroidism was significantly higher in older people living in a region with excess iodine intake than those living in a region with deficient iodine intake (21).

In a study in Switzerland, the prevalence of hyperthyroidism increased by $27 \% 1$ year after iodization, but this prevalence decreased by $44 \%$ after 9 years (33). When the etiology of hyperthyroidism was evaluated, the prevalence of toxic multinodular goitre decreased by $73 \%$ and Graves disease by 33\% compared with baseline (33). Similarly, in our study, the prevalence of hyperthyroidism decreased after iodization. In a similar study in Austria, in the second year after iodization, the prevalence of both toxic nodular goitre and Graves disease increased. However, 5 years after iodization, the prevalence of toxic nodular goitre fell to a level close to before iodization and Graves disease increased in all age groups and both sexes, while the prevalence of toxic nodular goitre increased in older people (34). In our study, toxic nodular goitre was the most common cause of hyperthyroidism in our elderly participants. In contrast to other studies, a Danish study reported that the frequency of hyperthyroidism increased significantly in young people 6 years after iodization, although the frequency of hyperthyroidism was not significantly increased in older people (26). In a 5-year follow-up study in China, there was no difference in the prevalence of hyperthyroidism in three regions with mild iodine deficiency, excess iodine intake and excessive iodine intake (25). Another study in China found no changes in the prevalence of clinical hyperthyroidism, subclinical hyperthyroidism or Graves disease 15 years after iodization in 10 cities (35).

In our study, thyroid autoantibody was high in $13.3 \%$ of our participants: $9.3 \%$ had a high antithyroid peroxidase antibody level, $9.0 \%$ had a high anti-thyroglobulin antibody level and 5.0\% had high levels of both antibodies. Thyroid autoantibodies levels were high in $16.8 \%$ of women and in $9.7 \%$ of men, a statistically significant difference $(P<0.001)$. In 1999, the frequency of thyroid autoantibody positivity was $24.5 \%$ in elderly people in Ankara (14). In some comparative studies of elderly people, the prevalence of autoantibodies was similar in iodine-deficient and iodine-sufficient areas (36). However, a study of elderly people in two European countries with sufficient iodine intake, reported the prevalence of thyroid autoantibodies was $24.4 \%$ and $32 \%(22,23)$. A study on iodine deficiency in old age reported more frequent (up to $42 \%$ ) thyroid autoantibodies in older people in iodine-deficient areas (37). A study in Brazil, reported that anti-thyroid peroxidase was detected in 9\% of the elderly participants with mean urinary iodine concentration of $210 \mu \mathrm{g} / \mathrm{L}$, which is similar to our study (19). A study in Poland found a significant increase in thyroid antibody positivity levels after iodization (27). Some studies have found no difference between thyroid antibody positivity levels before and after iodization (38-40).

Our study showed that iodine levels had not yet reached the desired levels in older people in Turkey 10 years after iodization, which was a mild-to-moderate iodine deficiency area before 1999. The frequency of goitre and hyperthyroidism decreased and the frequency of hypothyroidism increased. In order to provide information about thyroid function tests after adequate iodine levels are reached, further studies are needed.

To our knowledge this is the only population-based screening study on urinary iodine concentration and frequency of thyroid diseases of the older population after iodization in Turkey. In order to have as large a sample as possible, we only excluded participants with a chronic disease that would affect the laboratory results, those with incomplete laboratory results and those for whom we were unable to obtain samples. Nevertheless, our study has some limitations. There were no records of thyroid disease and iodine levels of the study population before iodization. Therefore, we used verbal declarations of participants in their disease history. In addition, participants were mobile patients, so we could not access data of elderly people who were not able to move out of their home. Although this was a screening study, our population was only Mamak, the fourth largest district of Ankara, the capital of Turkey. Thus, our results may not be fully representative of the whole country. Finally, iodine content of food and water varies greatly but we had no data on the food intake of our participants so cannot comment on the source of iodine of our participants.

\section{Conclusion}

Iodine levels, even after 10 years of iodization, have not yet reached the desired levels in older people in Turkey and this group is still mildly deficient in iodine. The prevalence of goitre and hyperthyroidism seems to have decreased after iodization, while that of hypothyroidism seems have increased. It is necessary to continue to encourage increased iodine intake in order to achieve more adequate iodine levels in elderly people. However, older people may follow diets with salt restriction because of conditions such as hypertension, heart failure and chronic renal disease. Therefore, iodization of salt may not be enough to correct iodine deficiency in such people. Other options to increase iodine consumption may be to iodize oil or water or to provide iodized tablets for selected individuals.

Funding: None.

Competing interests: None declared. 


\section{Concentration d'iode et prévalence des maladies de la thyroïde chez les personnes âgées après l'iodation du sel en Turquie}

\section{Résumé}

Contexte : L'absorption de l'iode est un facteur principal affectant les maladies de la thyroïde. En Turquie, l'iodation obligatoire du sel a débuté en 1999-2000.

Objectifs : En 2009, la présente étude a déterminé la prévalence de maladies de la thyroïde chez les personnes âgées dans le district de Mamak, à Ankara, après l'iodation, afin de déterminer si l'iodation du sel seule est suffisante pour atteindre des taux d'iode adéquats dans la population de personnes âgées.

Méthodes: Tous les résidents de Mamak âgés de 65 ans et plus pouvaient être inclus dans l'étude. Les données démographiques et les antécédents médicaux ont été enregistrés. Tous les participants ont eu une échographie thyroïdienne. Des échantillons de sang ont été prélevés pour évaluer la fonction thyroïdienne et les auto-anticorps, et on a procédé à des prélèvements d' échantillons d'urine pour évaluer la concentration en iode. Les participants présentant de faibles taux de thyréostimuline ont été soumis à une scintigraphie pour évaluer la fixation de la thyroïde. Une ponction à l'aiguille fine a été réalisée pour les nodules supérieurs ou égaux à 1,5 cm lorsque l'hormone thyréostimulante n'était pas supprimée.

Résultats : Sur 1200 résidents admissibles, 979 ont été inclus. Leur âge moyen était de 70,9 ans (écart type (ET) 5,7 ans) ; $49,7 \%$ étaient des femmes. La concentration moyenne d'iode urinaire était de $98(\mathrm{ET} 81,29) \mu \mathrm{g} / \mathrm{L}$. Un goitre a été retrouvé chez 18,2 \% (89/487) des femmes et 6,7\% (33/492) des hommes ( $p<0,001)$ et 43,8 \% (428/979) avaient des nodules. Une hypothyroïdie subclinique a été observée chez 5,8 \% (57/979) des participants, une hyperthyrö̈die manifeste chez $0,8 \%$ (8/979), une hyperthyroïdie subclinique chez 2,2 \% (22/979) et une thyrotoxicose T3 chez 0,3\% (3/979). Le goitre multinodulaire toxique et l'adénome toxique ont causé $80 \%$ des cas d'hyperthyroïdie. La biopsie n'a retrouvé aucune pathologie maligne.

Conclusion: Après l'iodation du sel, les taux d'iode n'avaient pas encore atteint des niveaux favorables chez les personnes âgées. L'iodation du sel semble insuffisante pour atteindre ces taux chez les personnes âgées ; une supplémentation alternative en iode devrait être envisagée.

$$
\begin{aligned}
& \text { تر كيز اليود ومعدل انتشار أمر اض الغدة الدرقية في أوساط المُسنّين بعد إضافة اليود إلى الملح في تركيا } \\
& \text { فولكان أتميس، بكيت بولبول، رمزي بهشي، ميسو جومسوي، أحمديالجين، زينال دوجان، أوزجور ديمير، مراد أردوجان، تسليم آتلي } \\
& \text { الخالاصة }
\end{aligned}
$$

الخلفية: يمثل امتصاص اليود عاملاً رئيسياً في التأثير على أمراض الغدة الدرقية. وفي تركيا، أصبحت إضافة اليود إلى الملح إلز امية في الفترة - 1999 .2000

الأهداف: هدفت هذه الدراسة التي أجريت في عام 2009 إلى تحديد معدل انتشار أمراض الغدة الدرقية في صفوف كبار السن في منطقة ماماك

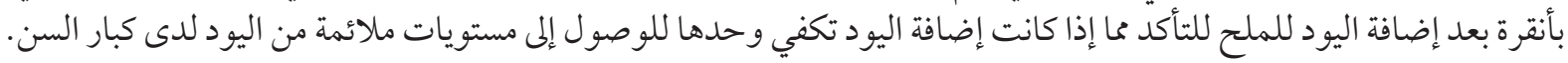

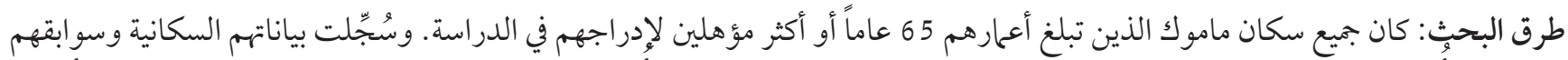

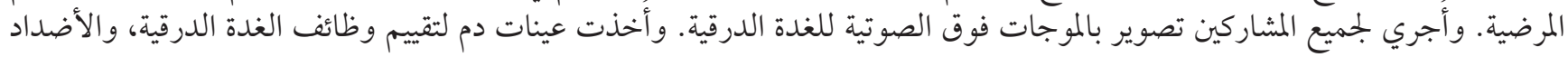

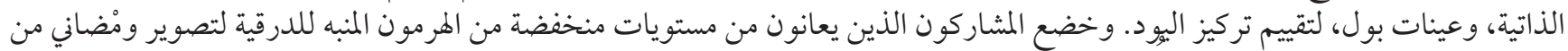

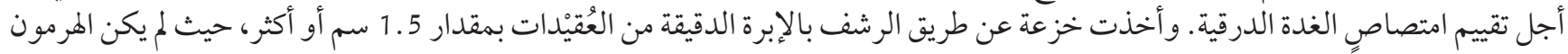
المنبه للدرقية مكبوتاً.

النتائج: من بين 1200 من المقيمين المؤهلين ، تم تضمين 4979 و. كان متوسط أعحارهم 70.9 سنة (الانحراف المعياري (SD 5.7) سنة.

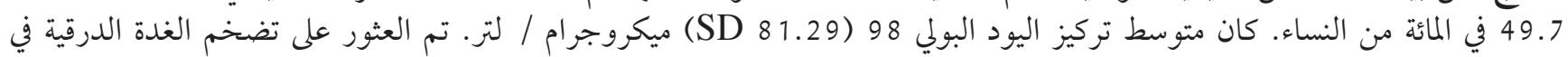

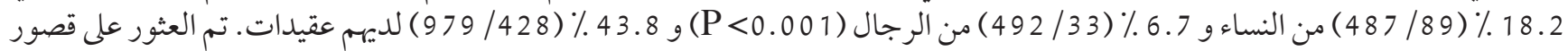

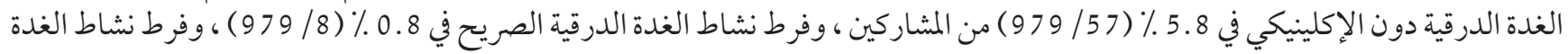

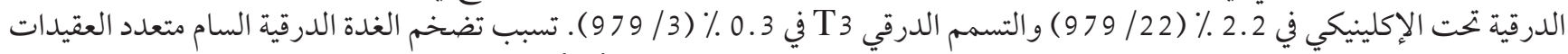

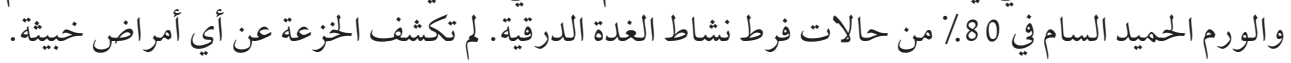

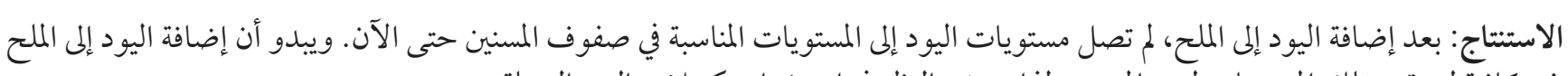

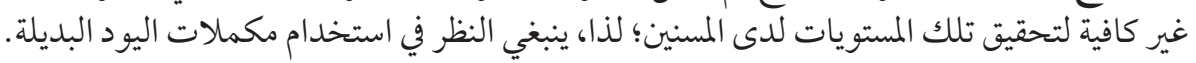




\section{References}

1. Nilsson M, Fagman H. Development of the thyroid gland. Development. 2017;144(12):2123-40. http://doi.org/10.1242/dev.145615

2. Mondal S, Raja K, Schweizer U, Mugesh G. Chemistry and biology in the biosynthesis and action of thyroid hormones. Angew Chem Int Ed Engl. 2016;55(27):7606-30. http://doi.org/10.1002/anie.201601116

3. Perrine CG, Cogswell ME, Swanson CA, Sullian MK, Chen T, et al. Comparison of population iodine estimates from 24-hour urine and timed-spot urine samples. Thyroid. 2014; 24(4): 748-57. http://doi.org/10.1089/thy.2013.0404

4. Assessment of iodine deficiency disorders and monitoring their elimination: a guide for programme managers, third edition. Geneva: World Health Organization; 2007 (https://apps.who.int/iris/bitstream/handle/10665/43781/9789241595827_eng.pdf?sequence $=1$, accessed 4 June 2020).

5. Sun X, Shan Z, Teng W. Effects of increased iodine intake on thyroid disorders. Endocrinol Metab (Seoul). 2014;29(3):240-7. http://doi.org/10.3803/EnM.2014.29.3.240

6. Ajish TP, Jayakumar RV. Geriatric thyroidology: an update. Indian J Endocrinol Metab. 2012;16(4):542-7. http://doi. org/10.4103/2230-8210.98006

7. Halter JB, Ouslander JG, Studenski S, High KP, Asthana S, Supiano MA, et al, editor. Hazzard's Geriatric Medicine and Gerontology, seventh edition. New York: McGraw Hill Professional; 2016: pp 1625-39.

8. Paschou SA, Vryonidou A, Goulis DG. Thyroid nodules: alpha guide to assessment, treatment and follow-up. Maturitas. 2017;96:1-9. http://doi.org/10.1016/j.maturitas.2016.11.002

9. İyot Yetersizliği Hastalıkları ve İyotlu Tuz Rehberi. Sağlık Bakanlığı İyot Yetersizliği Hastalıklarının Önlenmesi ve İyotlu Tuz Progamı [Prevention of iodine deficiency diseases and iodized salt program. iodine deficiency diseases and iodized salt guide]. Ankara: Ministry of Health; 2000 (https://www.resmigazete.gov.tr/eskiler/2000/08/20000815.htm\#5, accessed 23 June 2010).

10. Erdoğan MF, Agbaht K, Altunsu T, Ozbas S, Yücesan F, Tezel B, et al. Current iodine status in Turkey. J Endocrinol Invest. 2009;32(7):617-22. http://doi.org/10.1007/BF03346519

11. Erdoğan MF, Demir Ö, Emral R, Kamel AN, Erdogan G. More than a decade of iodine prophylaxis is needed to eradicate goiter among school age children in a moderately iodine-deficient region. Thyroid. 2009;19(3):265-8. http://doi.org/10.1089/ thy.2008.0253

12. Brunn J, Block U, Ruf G, Bos I, Kunze WP, Scriba PC. Volumetrie der schilddrüsenlappen mittels real-time-sonographie [Volumetric analysis of thyroid lobes by real-time ultrasound]. Dtsch Med Wochenschr. 1981;106(41):1338-40. http://doi. org/10.1055/s-2008-1070506

13. Hegedus L, Perrild H,Poulsen L R, Andersen JR, Holm B, Schnohr P, et al. The determination of thyroid volume by ultrasound and its relationship to body weight, age, and sex in normal subjects. J Clin Endocrinol Metab. 1983;56(2):260-3. http://doi. org/10.1210/jcem-56-2-260

14. Erdoğan MF, Atli T, Ekinci C, Genç Y, Gökmen H, Erdoğan G. Orta derece iyot eksikliği olan bir bölgede yaşayan yaşlılardaki tiroid hastalıkları spektrumu ve prevalansı [Spectrum and prevalence of thyroid diseases in elderly people living in a region with moderate iodine deficiency]. Turk J Geriatr. 2002;5(2):49-53.

15. Azizi F, Navai L, Fattahi F. Goiter prevalence, urinary iodine excretion, thyroid function and anti-thyroid antibodies after 12 years of salt iodization in Shahriar, Iran. Int J Vitam Nutr Res. 2002;72(5):291-5. http://doi.org/10.1024/0300-9831.72.5.291

16. Laurberg P, Pedersen KM, Hreidarsson A, Sigfusson N, Iversen E, Knudsen PR. Iodine intake and the pattern of thyroid disorders: abnormalities in the elderly in Iceland and Jutland, Denmark. Journal of Clinical Endocrinology and Metabolism. 1998;83(3):765-9. http://doi.org/10.1210/jcem.83.3.4624

17. Vanderpump MP, Tunbridge WM, French JM, Appleton D, Bates D, Clark F, et al. The incidence of thyroid disorders in the community: a twenty-year follow-up of the Whickham survey. Clin Endocrinol. 1995;43(1):55-68. http://doi. org/10.1111/j.1365-2265.1995.tbo1894.x

18. Aminorroaya A, Amini M, Hovsepian S. Prevalence of goitre in Isfahan, Iran, fifteen years after initiation of universal salt iodization. J Health Popul Nutr. 2010;28(4):351-8. http://doi.org/10.3329/jhpn.v28i4.6041

19. Duarte GC, Tomimori EK, Camargo RYA, Rubio IGS, Wajngarten M, Rodrigues AG, et al. The prevalence of thyroid dysfunction in elderly cardiology patients with mild excessive iodine intake in the urban area of Sao Paulo. Clinics (Sao Paulo). 2009;64(2):135-42. http://doi.org/10.1590/s1807-59322009000200011

20. Safran M, Paul TL, Braverman LE. Environmental factors affecting autoimmune thyroid disease. Endocrinol Metab Clin North Am. 1987;16(2):327-42.

21. Andersen S, Iversen F, Terpling S, Pedersen KM, Gustenhoff P, Laurberg P. More hypothyroidism and less hyperthyroidism with sufficient iodine nutrition compared to mild iodine deficiency--a comparative population-based study of older people. Maturitas, 2009;64(2):126-31. http://doi.org/10.1016/j.maturitas.2009.08.007

22. Szabolcs I, Podoba J, Feldkamp J, Dohan O, Farkas I, Sajgo M, et al. Comparative screening for thyroid disorders in old age in areas of iodine deficiency, long-term iodine prophylaxis and abundant iodine intake. Clin Endocrinol (Oxf). 1997;47(1):87-92. http://doi.org/10.1046/j.1365-2265.1997.2271040.x

23. Thorpe-Beeston JG, Nicolaides KH, McGregor AM. Fetal thyroid function. Thyroid. 1992;2(3):207-17. http://doi.org/10.1089/ thy.1992.2.207 
24. Fade JV, Franklyn JA, Cross KW, Jones SC, Sheppard MC. Prevalence and follow-up of abnormal thyrotrophin (TSH) concentrations in the elderly in the United Kingdom. Clin Endocrinol (Oxf). 1991;34(1):77-83. http://doi.org/10.1111/j.1365-2265.1991.tbo1739.x

25. Teng W, Shan Z, Teng X, Guan H. Effect of iodine intake on thyroid diseases in China. N Engl J Med. 2006;354(26):2783-93. http://doi.org/10.1056/NEJMoa054022

26. Pedersen IB, Laurberg P, Knudsen N, Jorgensen T, Perrild H, Ovesen L, et al. An increased incidence of overt hypothyroidism after iodine fortification of salt in Denmark: a prospective population study. J Clin Endocrinol Metab. 2007;92(8):3122-7. http:// doi.org/10.1210/jc.2007-0732

27. Gotkowski F, Bereza MB, Trofimiuk M, Waligorska AB. Increased prevalence of hyperthyroidism as an early and transient side-effect of implementing iodine prophylaxis. Public Health Nutr. 2007;10(8):799-802. http://doi.org/10.1017/ S1368980007585939

28. Zimmermann MB, Jooste P, Pandav CS. Iodine-deficiency disorders. Lancet. 2008;372(9645):1251-62. http://doi.org/10.1016/So1406736(08)61005-3

29. Bajuk V, Zaletel K, Pirnat E, Hojker S, Gaberscek S. Effects of adequate iodine supply on the incidence of iodine-induced thyroid disorders in Slovenia. Thyroid. 2017; 27(4):558-66. http://doi.org/10.1089/thy.2016.0186

30. Sundick RS, Bagchi N, Brown TR. The role of iodine in thyroid autoimmunity: from chickens to humans: a review. Autoimmunity. 1992;13(1):61-8. http://doi.org/10.3109/08916939209014636

31. Harach HR, Williams ED. Thyroid cancer and thyroiditis in the goitrous region of Salta, Argentina, before and after iodine prophylaxis. Clin Endocrinol (Oxf). 1995;43(6):701-6. http://doi.org/10.1111/j.1365-2265.1995.tboo538.x

32. Langer R, Burzler C, Bechtner G, Gartner R. Influence of iodide and iodolactones on thyroid apoptosis. Evidence that apoptosis induced by iodide is mediated by iodolactones in intact porcine thyroid follicles. Exp Clin Endocrinol Diabetes. 2003;111(6):325-9. http://doi.org/10.1055/s-2003-42721

33. Baltisberger BL, Minder CE, Bürgi H. Decrease of incidence of toxic nodular goitre in a region of Switzerland after full correction of mild iodine deficiency. Eur J Endocrinol. 1995;132(5):546-9. http://doi.org/10.1530/eje.0.1320546

34. Mostbeck A, Galvan G, Bauer P, Eber O, Atefie K, Dam K, et al. The incidence of hyperthyroidism in Austria from 1987 to 1995 before and after an increase in salt iodization in 1990. Eur J Nucl Med. 1998;25(4):367-74. http://doi.org/10.1007/s002590050234

35. Shan Z, Chen L, Lian X, Liu C, Shi B, Shi L, et al. Iodine status and prevalence of thyroid disorders after introduction of mandatory universal salt iodization for 16 years in China: a cross-sectional study in 10 cities. Thyroid. 2016;26(8):1125-30. http://doi. org/10.1089/thy.2015.0613

36. Latrofa F, Pichera A. Autoimmune hypothyroidism. In: Weetman AP, editor. Autoimmune diseases in endocrinology. Berlin: Springer Science+Business Media; 2008.

37. Andersen S, Iversen F, Terpling S, Pedersen KM, Gustenhoff P, Laurberg P. Iodine deficiency influences thyroid autoimmunity in old age a comparative population-based study. Maturitas. 2012;17(1):39-43. http://doi.org/10.1016/j.maturitas.2011.10.001

38. Loviselli A, Velluzzi F, Mossa P, Cambosu MA, Secci G, Atzeni F, et al. The Sardinian Autoimmunity Study: 3. Studies on circulating antithyroid antibodies in Sardinian schoolchildren: relationship to goiter prevalence and thyroid function. Thyroid. 2001;11(9):849-57. http://doi.org/10.1089/105072501316973109

39. Prentice LM, Philips DI, Sarsero D, Beever K, McLahlan S, Smith BR. Geographical distribution of subclinical autoimmune thyroid disease in Britain: a study using highly sensitive direct assays for autoantibodies to thyroglobulin and thyroid peroxidase. Acta Endocrinol (Copenh). 1990;123(5):493-8. http://doi.org/10.1530/acta.0.1230493

40. Tammaro A, Pigliacelli F, Fumarola A, Persechino S. Trends of thyroid function and autoimmunity to 5 years after the introduction of mandatory iodization in Italy. Eur Ann Allergy Clin Immunol. 2016;48(3):77-81. 